\title{
Structural and Optical Properties of Nickel Sulfoselenide (NiSSe) Thin Film for Photoelectrochemical Applications
}

\author{
S. Shariza, T. Joseph Sahaya Anand* and Nurul Hazliza \\ Faculty of Manufacturing Engineering, Universiti Teknikal Malaysia Melaka, \\ Hang Tuah Jaya, 76100, Durian Tunggal, Melaka, Malaysia.
}

Received 30 September 2017; accepted 20 March 2018; available online 1 August 2018

DOI: https://10.30880/jst.2018.10.02.009

\begin{abstract}
The transition metal, nickel is a favourable material to create combination with chalcogenides elements ( $\mathrm{S}, \mathrm{Se}$ and $\mathrm{Te}$ ) to become either binary or ternary transition metal chalcogenide such $\mathrm{NiSe}_{2}$, $\mathrm{NiSe}_{\text {, }}$ $\mathrm{NiS}_{2}$ and $\mathrm{Ni}_{3} \mathrm{Se}$. Throughout some observation from the previous research regarding the synthesis of ternary transition metal chalcogenide thin film for photoelectrochemical application, the combination of nickel with two chalcogenide elements; $\mathrm{S}$ and Se are rarely found due to the nature of selenium and sulphur. In this work, NiSSe thin film is being synthesis onto indium tin oxide (ITO) glass substrates using electrodeposition technique and the structural and optical properties of the films are studied. The resulted thin films are characterized using X-ray diffraction analysis and scanning electron microscope to determine the crystallographic and morphological properties. Optical are also being analysed for their bandgap values in other to determine the suitability of NiSSe thin film for photoelectrochemical properties. Results proved that nickel sulfoselenide thin films are polycrystalline in nature with a good uniformity. The intersection point for the optical analysis gave the direct bandgap. Well-adherent and dark-coloured thin films are derived from the cathodically electrodeposition by using potential in the reduction region. Experimental results proved NiSSe thin films are capable to be used in photoelectrochemical cell application.
\end{abstract}

Keyword: Thin film; Electrodeposition; Indium tin oxide (ITO) glass; Nickel sulfoselenide (NiSSe); Photoelectrochemical

\section{Introduction}

Usable electric current can be synthesized from photoelectrochemical cells. The unit cells are group together to form a series of solar panel. The arrays of solar panel are generally placed under glass, polymer or plastic as a protection from the weather [1]. The usage of transition metal chalcogenide thin film in solar energy conversion can lead to a good path in developing a bright future for photovoltaic application.

Transition metal chalcogenide are materials of semiconductors, which are capable to be used as an efficient photovoltaic material [2-4]. From the previous research, transition metal chalcogenides $\mathrm{NiX}_{2}(\mathrm{X}=\mathrm{Se}, \mathrm{S}$ and $\mathrm{Te})$ and $\mathrm{MoX}_{2}(\mathrm{X}=\mathrm{Se}, \mathrm{S}$ and Te$)$ have been showing a good result in term of optical and semiconducting properties as a new thin film material for solar energy in effort to replace the conventional method [5-10]. Transition metal chalcogenide thin films preparation by electrochemical methods is attracting to be given a special attention as it is relatively affordable, simple and convenient for large area deposition [5].

Good quality films can be potentially produced by changing the deposition parameters; for example bath temperature, $\mathrm{pH}$ of the bath, concentration of the solution and deposition time. The thin films are prepared on conducting tin oxide coated glass substrates as well as silicon and metal substrates [6-10].

Transition metal chalcogenides $\left(\mathrm{MX}_{2}\right)$ where $\mathrm{M}=\mathrm{Ni}$ and $\mathrm{X}=\mathrm{S}$ or $\mathrm{Se}$ in term of $\mathrm{NiSe}_{2}$ and NiS2 type structure are often used for solar energy conversion in photoelectrochemical solar cells $[6,7,11,12]$. The dichalcogenides of Ni derivative are much more attracted due to the well matched band gap $\left(\mathrm{E}_{\mathrm{g}}\right)$ with solar spectrum and specific lattice structure. In this research, the derivation from the method of producing $\mathrm{NiSe}_{2}$ thin film [6] and $\mathrm{NiS}_{2}$ [7] are implemented to produce the NiSSe thin film. The synthesis of the thin film from the growth mechanism until the characterization of the resulted film including compositional, 
structural, optical and semiconductor analysis are investigated in order to determine the properties of the combination NiSSe thin films.

\section{Experimental Procedures}

\section{Preparation of ITO Glass Substrates and Electrolyte}

Firstly, the ITO conductive glass substrates are immersed in ethanol and distilled water. The impurities on the glass slide are ultrasonically cleaned in ethanol and subsequently in distilled water for 10 minutes each at $60^{\circ} \mathrm{C}[13,14]$. Then, they are dried in mechanical convection oven at $60^{\circ} \mathrm{C}$ for 5 minutes [15]. The electrolyte use to deposit the NiSSe thin film is derived from aqueous solution of $0.05 \mathrm{M}$ nickel (II) sulfate hexahydrate $\left(\mathrm{NiSO}_{4} .6 \mathrm{H}_{2} \mathrm{O}\right), 0.05 \mathrm{M}$ selenium dioxide $\left(\mathrm{SeO}_{2}\right)$ and $0.05 \mathrm{M}$ sodium thiosulfate pentahydrate $\left(\mathrm{Na}_{2} \mathrm{~S}_{2} \mathrm{O}_{3} .5 \mathrm{H}_{2} \mathrm{O}\right)$ diluted in $100 \mathrm{ml}$ distilled water. Each material supplies the required $\mathrm{Ni}^{2+}, \mathrm{Se}^{2-}$ and $\mathrm{S}^{-}$ respectively. The ratio molar ratio between each material is selected to be $1: 1: 1$ [10]. 0.03M of additive triethanolamine (TEA) is added into the solution for improving the longevity of the deposition electrolyte as well as the adhesion of the deposited films [16]. To acquire alkaline condition, sodium hydroxide is added to help the formation of $\mathrm{Se}^{2-}$ and $\mathrm{S}^{-}$from $\mathrm{SeO}_{2}$ and $\mathrm{Na}_{2} \mathrm{~S}_{2} \mathrm{O}_{3} .5 \mathrm{H}_{2} \mathrm{O}$ respectively [11].

\section{Cyclic Voltammetry (CV), Electrochemical Deposition and Characterization Techniques}

The range of potential limit between -2.00 to $2.00 \mathrm{~V}$ for cyclic voltammetry $(\mathrm{CV})$ is selected to determine the suitable potential rate for the electrodeposition to take place by using Princeton Applied Research Model VersaSTAT 3 Potentiostat [16]. Once the suitable deposition potential has been set, the deposition time for the thin films are selected at 10 minutes, 15 minutes, 20 minutes, 25 minutes and 30 minutes. Bath temperature of the electrolyte solution is maintained at $40 \pm 3{ }^{\circ} \mathrm{C}$. Fig. 1 show the cyclic voltammetry and electrodeposition experimental set-up.

Thin film thickness was measured using gravimetric weight difference method. X-ray diffractograms of the thin film is obtained from a PAN analytical XPERT PROMPD PW 3040/60 diffractometer using monochromatic
$\mathrm{Cu} \mathrm{K} \alpha$ radiation $(\lambda=1.5148 \AA)$ at $2 \theta$ in the range of $15^{\circ}-70^{\circ}$.

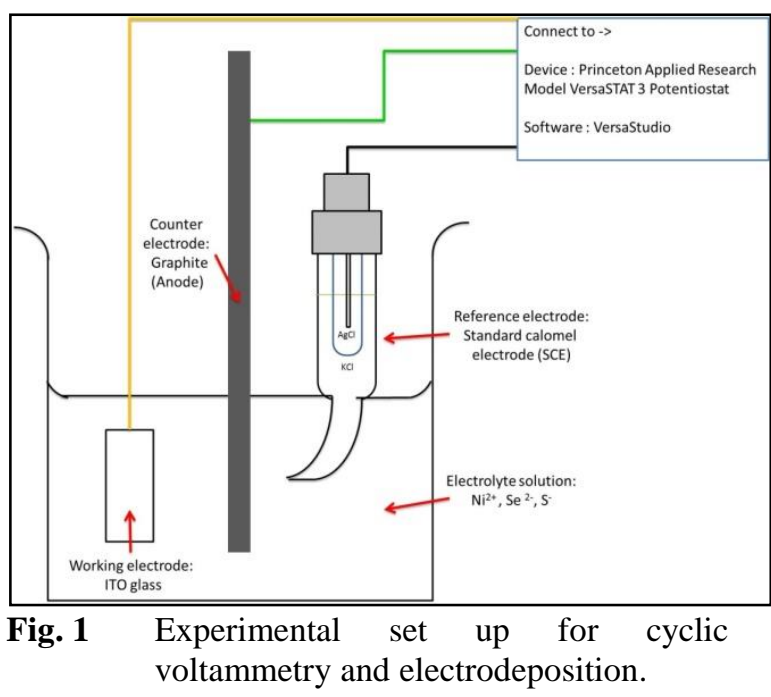

The morphological analysis of NiSSe thin film was studied by using TM3030 Plus Tabletop Scanning Electron Microscope (SEM) while compositional study was conducted using SwiftED TM3030 Plus Energy Dispersive Xray Spectroscopy (EDX). Optical absorption are studied using Shimadzu 1700 UV-Vis Spectrophotometer in the wavelength region of 200-1100 nm.

\section{Results and Discussions}

\section{Cyclic Voltammetry (CV)}

In comparison with the previous research regarding $\mathrm{NiSe}_{2}$ thin film [6] and $\mathrm{NiS}_{2}$ thin film [7], the range of suitable deposition potential voltage to electrodeposited NiSSe thin film are in between the value for both $\mathrm{CV}$ value of $\mathrm{NiSe}_{2}$ and $\mathrm{NiS}_{2}$.

Fig. 2 shows the cyclic voltammetry of NiSSe where the forward scan begins to rise at higher potential, $-1.0 \mathrm{~V}$. Then, the current slightly decreases and the deposition reaction is again reconfirmed by the reverse scan where the interception current occurred at approximately $-1.5 \mathrm{~V}$. During the reverse scan, co-deposition occurs in the negative potential range, however the current value is reduced as the deposition potential is scanned towards more negative value (anodic region). Deposition potentials of $-0.9 \mathrm{~V}$ is chosen to deposit the NiSSe thin film. 


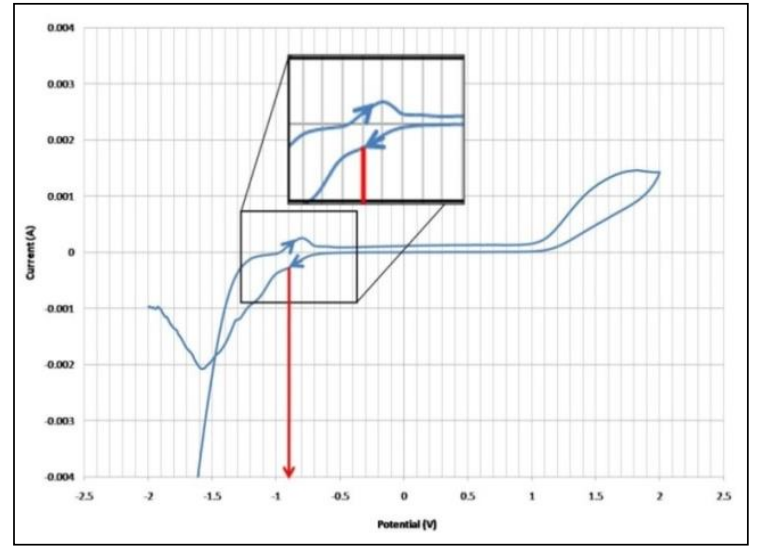

Fig. 2 Cyclic voltammogram of NiSSe.

Fig. 3 shows the appearance of thin films obtained. NiSSe forms dark coloured film on the ITO glass substrate. At 10 minutes and 15 minutes deposition time, almost no film forms.

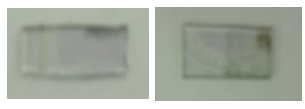

(i)

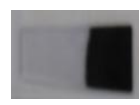

(ii)

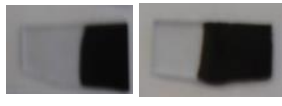

(iv) (v)
Fig. 3 Appearances of NiSSe thin films respected to different deposition time for (i) $10 \mathrm{~min}$, (ii) $15 \mathrm{~min}$, (iii) $20 \mathrm{~min}$, (iv) $25 \mathrm{~min}$ and (v) $30 \mathrm{~min}$.

\section{Kinetic and Growth Mechanism.}

Thin films NiSSe are deposited as the result of various chemical reactions take place in the deposition bath. The ionic reaction of nickel, sulphide and selenide are produced by the following reaction equilibria in an aqueous alkaline deposition bath.

$$
\begin{aligned}
& \mathrm{NiSO}_{4} \cdot 6 \mathrm{H}_{2} \mathrm{O} \longrightarrow \mathrm{Ni}^{2+}+\mathrm{SO}_{4}{ }^{2-}+6 \mathrm{H}_{2} \mathrm{O} \\
& \mathrm{SeO}_{2}+\mathrm{H}_{2} \mathrm{O} \longrightarrow \mathrm{H}_{2} \mathrm{SeO}_{3} \\
& \mathrm{H}_{2} \mathrm{SeO}_{3}+4 \mathrm{H}^{+}+6 \mathrm{e}^{-} \longrightarrow \mathrm{Se}^{2-}+3 \mathrm{H}_{2} \mathrm{O} \\
& \mathrm{Na}_{2} \mathrm{~S}_{2} \mathrm{O}_{3} \longleftrightarrow \mathrm{Na}^{2+}+\mathrm{S}_{2} \mathrm{O}_{3}{ }^{2-} \\
& \mathrm{S}_{2} \mathrm{O}_{3}{ }^{2-}+6 \mathrm{H}^{+}+6 \mathrm{e}^{-} \longleftrightarrow \mathrm{S}^{2-}+3 \mathrm{H}_{2} \mathrm{O}
\end{aligned}
$$

Based on equation 1, metals ions are produced by dissociation of metal complex. Equations 2 and 3 show the dissociation of sulphur and selenium precursors in the aqueous alkaline medium. The nucleation process starts after most of the ionic species $\mathrm{Ni}^{2+}, \mathrm{Se}^{2-}$ and $\mathrm{S}^{-}$ exceed in the nucleation bath resulting in the growth of $\mathrm{NiS}_{\mathrm{x}} \mathrm{Se}_{2-\mathrm{x}}(0 \leq \mathrm{x} \leq 2)$ thin films.
Based on formulation obtained from Anand \& Shariza [12], similar formulation for $\operatorname{MoS}_{\mathrm{x}} \mathrm{Se}_{2-\mathrm{x}}(0 \leq \mathrm{x} \leq 2)$ thin film is adopted in order to produced $\mathrm{NiS}_{\mathrm{x}} \mathrm{Se}_{2-\mathrm{x}}(0 \leq \mathrm{x} \leq 2)$ thin film and the kinetic growth can be understand based on the following equations 4,5 and 6 .

If $x=1$, NiSSe formation:

$$
\mathrm{Ni}^{2+}+\mathrm{Se}^{2-}+\mathrm{S}^{2-} \underset{\text { Nickel sulfoselenide }}{\longrightarrow} \mathrm{NiSe}_{2}
$$

The thickness of the thin films is calculated using the formula below, based on gravimetric weight difference method. Results of NiSSe film thickness is plotted in Fig. 4.

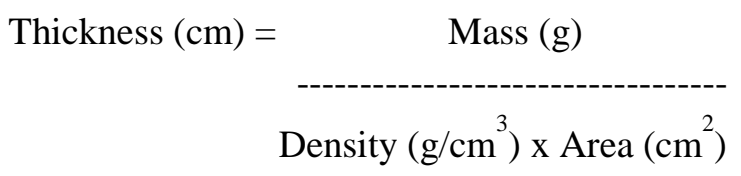

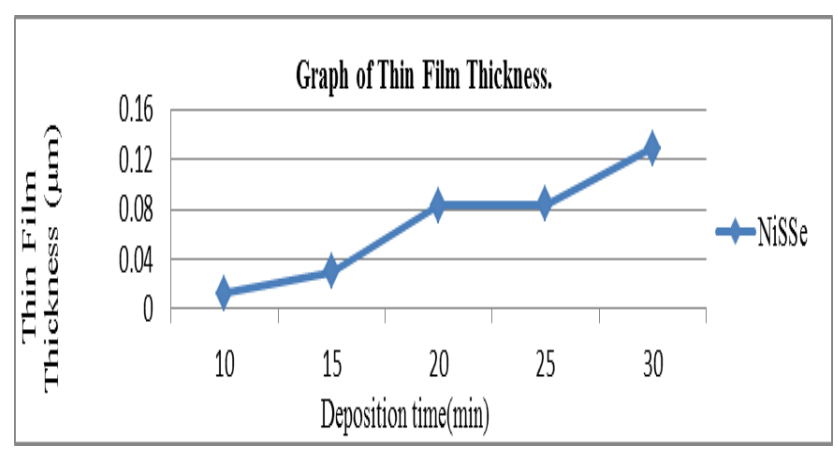

Fig. 4 Variation of NiSSe thin film thickness versus different deposition time.

The initial induction period is started approximately at 10 minutes deposition, where no clearly observable growth occurs. A very thin film formed can be observed. After that, the films begin to form. The growth mechanism as the nucleation occur performing initial induction of thin film following by the combination of ions for the subsequent linear film growth [17].

\section{Structural characterization}

The structural characterization and analysis using XRD are performed by set the incidence angle $1.5^{\circ}$ in order to reduce the intensity of the radiation reflected by the substrate [18]. Table 1 shows the comparison of ' $d$ ' values corresponded with Joint Committee of Powder Diffraction Standards (JCPDS). 
Table 1: Comparison of experimental'd' values with JCPDS data for NiSSe thin films.

\begin{tabular}{|c|c|c|c|c|c|c|c|c|}
\hline \multirow[b]{2}{*}{ Material } & \multirow[b]{2}{*}{$\begin{array}{c}\text { Angle } \\
(2 \theta)\end{array}$} & \multirow[b]{2}{*}{ ( h k l) } & \multirow{2}{*}{$\begin{array}{c}\text { Standard } \\
\AA \\
\text { 'd' } \\
\text { JCPDS }\end{array}$} & \multicolumn{5}{|c|}{ Experimental $(\AA)$} \\
\hline & & & & $10 \mathrm{~min}$ & $15 \mathrm{~min}$ & $20 \mathrm{~min}$ & $25 \mathrm{~min}$ & $30 \mathrm{~min}$ \\
\hline \multirow{4}{*}{ NiSSe } & 29.054 & $\left.\begin{array}{llll} & 1 & 0 & 0\end{array}\right)$ & 3.07093 & 2.94900 & 2.95542 & 2.95095 & 2.94080 & 2.96414 \\
\hline & 33.610 & $\left(\begin{array}{lll}1 & 0 & 1\end{array}\right)$ & 2.66433 & - & - & - & 2.65791 & 2.55347 \\
\hline & 60.222 & $\left(\begin{array}{lll}2 & 0 & 0\end{array}\right)$ & 1.53546 & 1.53207 & 1.53321 & 1.53299 & 1.53175 & 1.53294 \\
\hline & 62.915 & $\left(\begin{array}{llll}2 & 0 & 1\end{array}\right)$ & 1.47605 & 1.46743 & 1.46963 & - & - & - \\
\hline
\end{tabular}

Fig. 5 shows the different peaks obtained for NiSSe thin film electrodeposited at $-0.9 \mathrm{~V}$ of potential voltage with different deposition time. The thin films are polycrystalline by referring to the sharp peaks of the XRD pattern. Plane (1 $\left.\begin{array}{lll}0 & 1\end{array}\right)$ and $\left(\begin{array}{lll}1 & 1 & 0\end{array}\right)$ indicate the NiSSe thin film. The structural fit into hexagonal structure with lattice parameter value $\mathrm{a}=0.3546 \mathrm{~nm}$ and $\mathrm{b}=$ $0.3546 \mathrm{~nm}$ and $\mathrm{c}=0.5358 \mathrm{~nm}$ which comply in a good agreement with the standard value (JCDPS, ICDD, Card No. 01-089-7143).

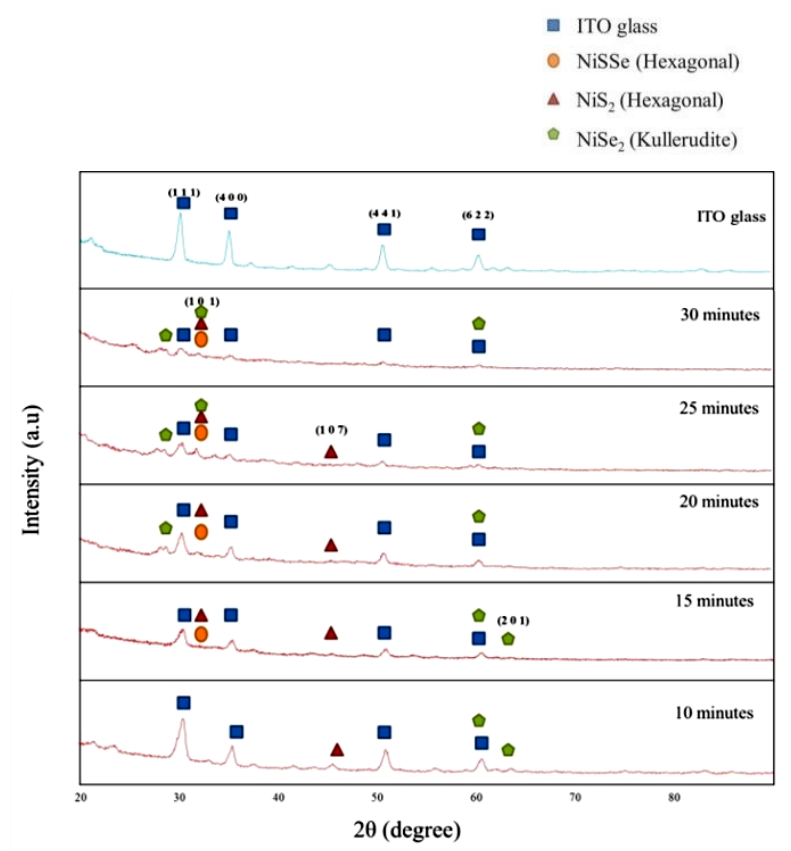

Fig. 5 X-ray diffraction pattern of NiSSe thin films deposited at various deposition time.

\section{Morphological Characterization}

The surface morphology of NiSSe thin films are shown in Fig. 6 deposited with different deposition time. It is recognized that the unsymmetrical crystallites forms on ternary chalcogenide films as observed in NiSSe thin film due to the separation of chalcogenides phases (selenium and sulphide) in a good agreement as reported in previous research involving ternary chalcogenides film $[10,19,20]$.

(a)

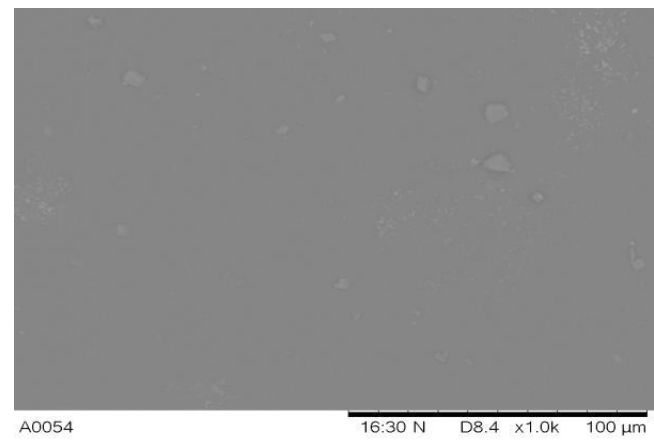

(b)

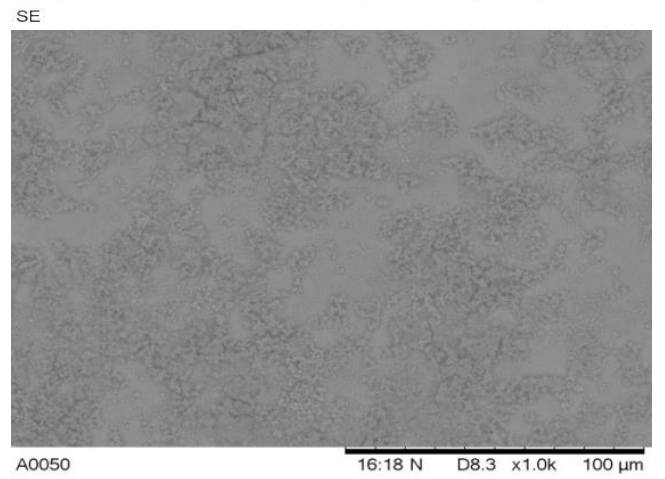

$\mathrm{SE}$ 
(c)

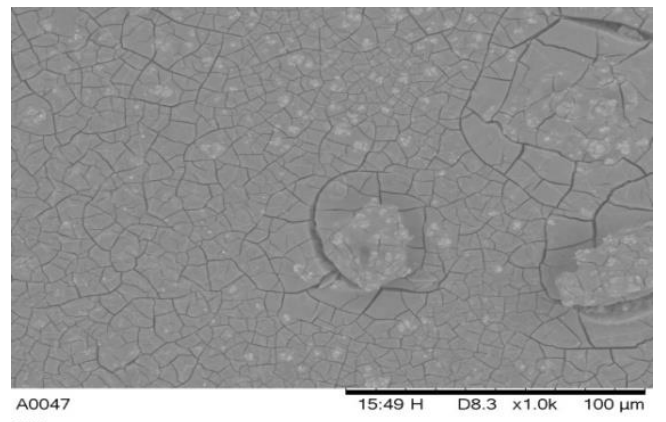

(d)

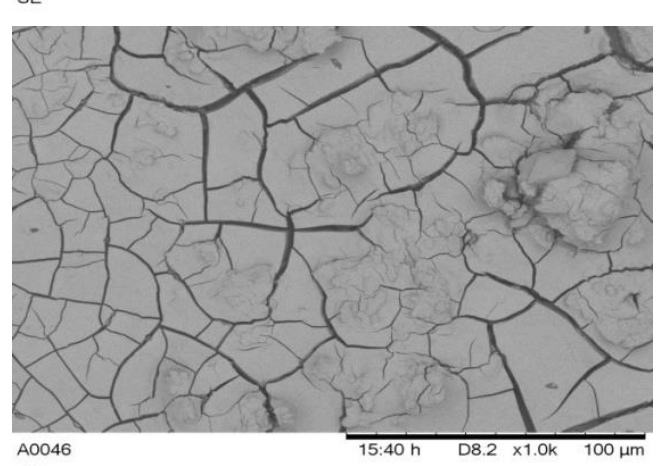

(e)

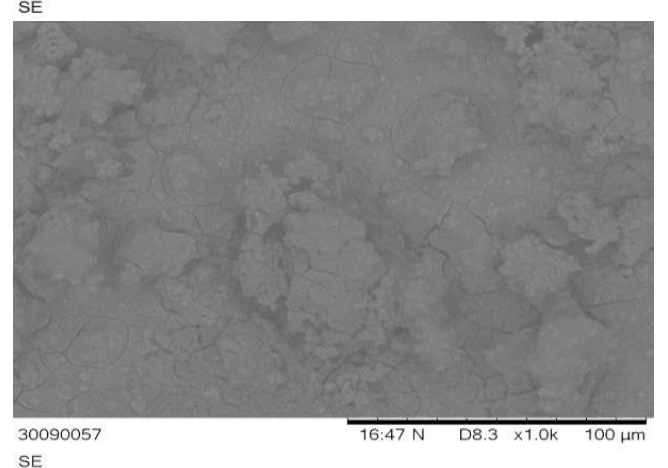

Fig. 6 SEM planar images of NiSSe thin film deposited at different deposition time under 1000x magnification. (a) $10 \mathrm{~min}$, (b) 15 min, (c) $20 \mathrm{~min}$, (d) $25 \mathrm{~min}$ and (e) $30 \mathrm{~min}$.

The deposited thin film distributions are almost homogeneous with good adherent. There are slightly deposited NiSSe thin films on the ITO glass at 10 minutes and 15 minutes deposition time as the time of deposition increase, the thin film obtained is much thicker and uniform. The present of selenium is found to produce better orientation of crystal structure in the ternary transition metal chalcogenide film [21]. As longer the deposition time, the thin films are still adhered to the substrate but the structures of the films start to break into grains or flakes upon reaching the maximum grain stress point. In hydrous films case, drying shrinkage is the main contribution to form crack on the deposited film [22].

\section{Compositional Characterization}

EDX patterns for NiSSe thin film deposited at 20 minutes is shown in Fig. 7. From the spectra, strong peaks for $\mathrm{Ni}, \mathrm{S}$ and $\mathrm{Se}$ were identified to confirm that mixed combinatorial films of NiSSe have been formed throughout the electrodeposition process.

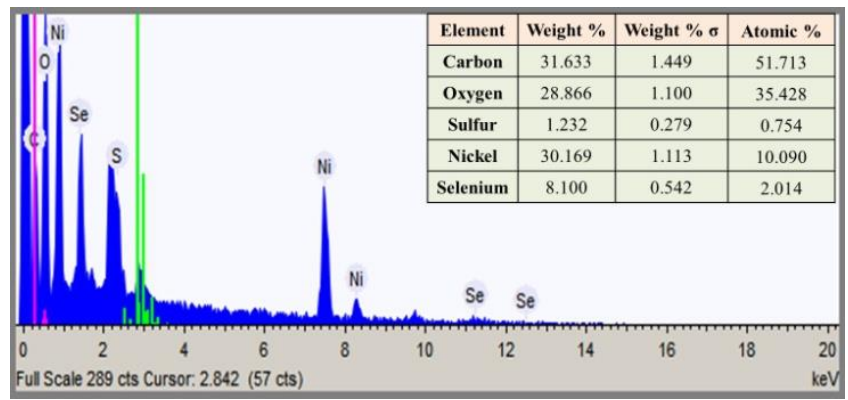

Fig. 7 EDX spectrum of deposited NiSSe thin film.

\section{Optical Characterization}

The optical absorption data were analyzed from the equation:

$$
\alpha=\frac{A\left(h v-E_{g}\right)^{n / 2}}{h v}
$$

where A is constant between $10^{7}$ and $10^{8} \mathrm{~m}^{-}$ ${ }^{1}, \mathrm{E}_{g}$ is the energy gap that occupies the area between the bottom of the conduction band and the top of the valence band at the same wave vector $K$ and $n$ is the constant equal to 1 for direct band gap and 4 for indirect bandgap [23].

The optical study shows the thin film of NiSSe has the properties of direct bandgap and are highly absorptive where the value of absorption coefficient, $\alpha$ at various wavelength has been calculated and found to be dependent on both radiation energy and composition [24].

Fig. 8 shows the band gap values obtain from the extrapolation of the plot of $(\alpha h v)^{2}$ with respect to photon energy, $\mathrm{E}_{g}$ for NiSSe thin film. The energy band gap increase from $0.1 \mathrm{eV}$ to $0.8 \mathrm{eV}$ as the deposition time increase and after 25 minutes, the energy band gap decrease to $0.7 \mathrm{eV}$. 


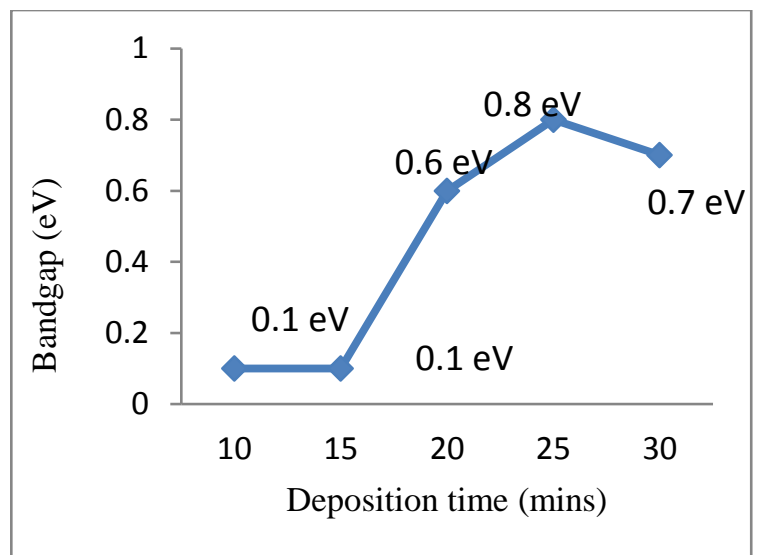

Fig. 8 The band gap values vs. deposition time of NiSSe thin film.

\section{Semiconductor Properties of NiSSe Thin Film}

A EDUTECH EDU 9100 B LCR - 7 bridge with an inbuilt function generator of a frequency of $1 \mathrm{kHz}$ was used for the measurement of space-charge capacitance to obtain Mott-Schottky plots drawn using the capacitance data at a frequency of $1 \mathrm{kHz}$ (in the dark) for the system $\mathrm{NiSSe} \mid \mathrm{K}_{2} \mathrm{SO}_{4}, \mathrm{KI}, \mathrm{I}_{2}$, $\mathrm{H}_{2} \mathrm{SO}_{4}$ |graphite. The Mott-Schottky plot drawn in the Fig. 9 shows the negative slopes, indicating that the deposited films fall in the ptype conductivity.

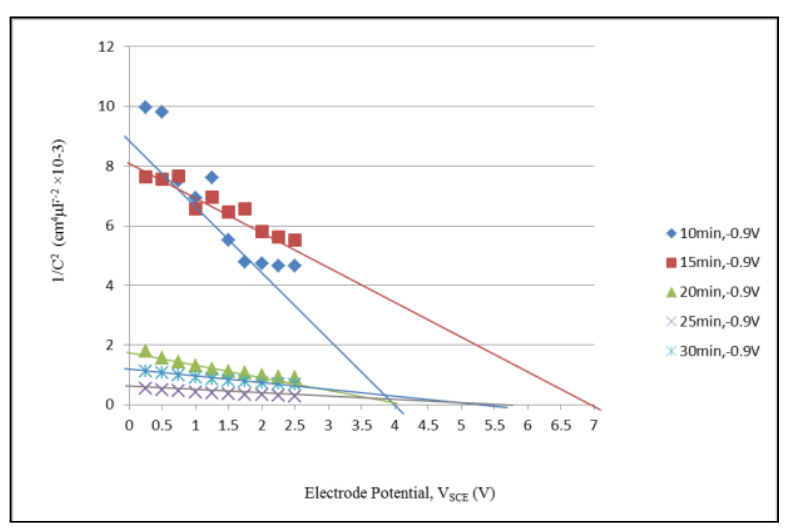

Fig 9 Mott-Schottky plot of NiSSe thin film.

The value of flat band potential $\left(\mathrm{V}_{\mathrm{fb}}\right)$ is obtained using the relation:

$$
1 / \mathrm{C}_{\mathrm{SC}}^{2}=\left(\mathrm{V}-\mathrm{V}_{\mathrm{fb}}-\mathrm{k}_{\mathrm{B}} \mathrm{T} / \mathrm{e}\right) 2 / \varepsilon \varepsilon_{\mathrm{O}} \mathrm{eN}_{\mathrm{D}}
$$

where $e_{O}$ is the dielectric constant of free space $\left(8,854 \times 10^{-12} \mathrm{~F} / \mathrm{m}\right), \varepsilon$ is the dielectric constant of NiSSe (6.52), e isthe electronic charge (1.603 $\times 10^{-19} \mathrm{C}$ ) and $\mathrm{N}_{\mathrm{D}}$ is the doping density which is calculated from the slope of the graph. $\mathrm{T}$ is the temperature of the operation $(300 \mathrm{~K})$ and $\mathrm{k}_{\mathrm{B}}$ is the Boltzmann's constant $(1.38 \times 10-23 \mathrm{~J} / \mathrm{K})$ and $\mathrm{C}_{\mathrm{SC}}$ is the space charge capacitance. The intercept of the linear plot $\left(1 / \mathrm{CSC}^{2}=0\right)$ was taken as the electrode potential of the semiconductor at which the bond bending is zero. The flat band potential of NiSSe thin films from the Mott-Schottky plots are given in Table 2.

Table 2 Flat band potential of NiSSe thin films.

\begin{tabular}{|l|l|}
\hline $\begin{array}{l}\text { As deposited sample with } \\
\text { respect to deposition time }\end{array}$ & $\begin{array}{l}\text { Flat band potential } \\
\left(\mathrm{V}_{\mathrm{fb}}\right)\end{array}$ \\
\hline$-0.9 \mathrm{~V}, 10 \mathrm{~min}$ & $4.0 \pm 0.02 \mathrm{~V}_{\mathrm{SCE}}$ \\
\hline$-0.9 \mathrm{~V}, 15 \mathrm{~min}$ & $7.0 \pm 0.02 \mathrm{~V}_{\mathrm{SCE}}$ \\
\hline$-0.9 \mathrm{~V}, 20 \mathrm{~min}$ & $4.5 \pm 0.02 \mathrm{~V}_{\mathrm{SCE}}$ \\
\hline$-0.9 \mathrm{~V}, 25 \mathrm{~min}$ & $5.0 \pm 0.02 \mathrm{~V}_{\mathrm{SCE}}$ \\
\hline$-0.9 \mathrm{~V}, 30 \mathrm{~min}$ & $3.75 \pm 0.02 \mathrm{~V}_{\mathrm{SCE}}$ \\
\hline
\end{tabular}

\section{Conclusion}

NiSSe thin films are successfully deposited on ITO-coated glass. All films obtained are well adhered to the substrates undergoing 'ion-byion' growth mechanism. From the cyclic voltammetry show that suitable deposition potential is $-0.9 \mathrm{~V}$. XRD analysis of the films proved that NiSSe thin films are polycrystalline in nature. The morphological characteristics show that the NiSSe are well distributed onto the ITO glass substrates. The presence of nickel, selenium and sulfur from mixed combinatorial had been confirmed via compositional study using EDX. Optical studies show the direct optical band gap energy of the film. Semiconductor parameters of the film revealed that the NiSSe thin films are ptype material showing that thin films are capable as photoelectrochemical cell material.

\section{Acknowledgements}

The work presented in this paper was supported by Universiti Teknikal Malaysia Melaka (UTeM) and MoHE sponsored FRGS (FRGS/2011/FKP/TK02/1/F00120).

\section{References}

[1] Dhanasekaran,V., Mahalingam, T., Rhee, J.K. and Chiu, J.P. (2013) "Structural and Optical Properties of Electrosynthesized ZnSe Thin Films" in Optik, Vol. 124, No. 3, pp. 255-260. 
[2] Yadav A.A. and Masumdar E.U. (2010) "Photoelectrochemical Performances of $n$ $\mathrm{CdS}_{1-\mathrm{x}} \mathrm{Se}_{\mathrm{x}}$ Thin films Prepared by Spray Pyrolysis Technique" in Solar Energy, Vol. 84, pp.1445.

[3] Gujarathi D.N, Solanki G.K, Deshpande M.P, and Agarwal M.K. (2006) "PEC Behaviour of Mixed Single Crystals of Tungsten Sulphoselenide Grown by a CVT Technique" in Solar Energy Materials and Solar Cells, Vol. 90, pp. 2630.

[4] Kokate A.V, Asabe M.R, Delekar S.D, Gavali L.V, Mulla L.S, Hankare P.P and Chougule B.K. (2006) "Photoelectrochemical Properties of Electrochemically Deposited $\mathrm{CdIn}_{2} \mathrm{~S}_{4}$ Thin Flms" in Journal of Physics and Chemistry of Solids, Vol. 67, pp. 2331.

[5] Pathan, H.M. and Lokhande, C.D. (2004) "Deposition of Metal Chalcogenide Thin Films by Successive Ionic Layer Adsorption and Reaction (SILAR) Method" in Bulletin Material Science, Vol. 27, No. 2, pp.85-111.

[6] Anand T.J.S, Zaidan M.A.A, Shariza S. (2013) "Effect of Additives on Optical Measurements of $\mathrm{NiSe}_{2}$ Thin Films" in Procedia Engineering, Vol. 53, pp. 555561.

[7] Anand, T.J.S., Rajes KM, R., and Mohd Zaidan A.A. (2013) "Electrosynthesized $\mathrm{NiS}_{2}$ Thin Film and Their Optical and Semiconductor Studies" in Reports in Electrochemistry, Vol. 3, pp. 25-29.

[8] Shariza, S. and Anand, T.J.S. (2011) "Effect of Deposition Time on The Structural and Optical Properties of Molybdenum Chalcogenides Thin Films" in Chalcogenide Letters, Vol. 8, No. 9, pp. 529-539.

[9] Anand, T.J.S. (2009) "Synthesis and Characterization of $\mathrm{MoS}_{2}$ Films for Photoelectrochemical Cells" in Sains Malaysiana, Vol. 38, No.1, pp.85-89.

[10] Anand, T.J.S., and Shariza S. (2012) "A Study on Molybdenum Sulphoselenide $\left(\mathrm{MoS}_{\mathrm{x}} \mathrm{Se}_{2-\mathrm{x}}, 0<\mathrm{x}<2\right)$ Thin Films: Growth from Solution and its Properties" in Electrochimica Acta, Vol. 81, pp.64-73.

[11] Zhongbin, Z., Qing, P., Jing, Z., Xun, W. and Yadong, L. (2006) "Controlled Hydrothermal Synthesis and Structural Characterization of a Nickel Selenide
Series" in Wiley Inter Science, Vol. 12, No. 10, pp.211-217.

[12] Zainal, Z., Saravanan, N. and Mien, H.L. (2005) "Electrodeposition of Nickel Selenide Thin Films in The Presence of Triethanolamine as a Complexing Agent" in Journal of Material Science: Materials in Electronics, Vol. 16, pp.111-117.

[13] Anuar, K., Saravanan, N., Wee, T.T., Soon, M.H. and Darren, T. (2016) "Chemical Bath Deposition of Nickel Sulphide $\left(\mathrm{Ni}_{4} \mathrm{~S}_{3}\right)$ Thin Films" in Leonardo Journal of Sciences, Vol. 16, pp.1-12.

[14] Hesson, JR (2012). Fundamental of Ultrasonic Cleaning High Energy Sound Supersonics, United State: Hessonic.

[15] Zhuang, Z, Peng, Q, Zhuang, J, Wang, X, and Yadong, L (2006) "Controlled Hydrothermal Synthesis and Structural Characterization of Nickel Selenide Series" in Chemistry A: European Journal, Vol. 12, pp. 211-217.

[16] Villamena, F.A., Horak, V. and Crist, R. (2003) "Cyclic Voltammetry of Metal Complexes of Nitrones and Nitroxides" in Inorganica Chimica Acta, Vol. 342, pp. 125-130.

[17] Hankare P.P, Bhuse V.M., Garadkar K.M., Delekar S.D., and Mulla I.S. (2003) "Low Temperature Route to Grow Polycrystalline Cadmium Selenide and Mercury Selenide Thin films" in Materials Chemistry and Physics, Vol. 82, pp. 711.

[18] Toma, O., Iftime, S., Besleaga, C., Mitran, T.L., Ghenescu, V., Porumb, O., Toderus, A., Radu, M., Ion, L. and Antohe, S. (2011) "New Investigations on Cadmium Sulfide Thin Films for Photovoltaic Applications" in Chalcogenide Letters, Vol. 8, No. 12, pp.747-756.

[19] Subramaniana, B., Sanjeevirajab, C., and Jayachandran, M. (2003) "Materials Properties of Electrodeposited $\mathrm{Sns}_{0.5} \mathrm{Se}_{0.5}$ films and Characterization of Photoelectrochemical Solar Cell" in Materials Research Bulletin, Vol. 38, pp. 899-908.

[20] Kumar R., Garima Jain, Ravindra Saini, and Pallavi Agarwal, (2010) "Compositional Effects on Properties of $\mathrm{PbS}_{1-\mathrm{x}} \mathrm{Se}_{\mathrm{x}}$ Thin Films" in Chalcogenide Letters, Vol. 7, No. 4, pp 233-240.

[21] Ajalkar, B.D., Mane, R.K., Sarwade, B.D. and Bhosale, P.N. (2004) "Optical and 
Electrical Studies on Molybdenum

Sulphoselenide $\quad\left[\mathrm{Mo}\left(\mathrm{S}_{1-\mathrm{x}} \mathrm{Se}_{\mathrm{x}}\right)_{2}\right] \quad$ Thin Films Prepared by Arrested Precipitation Technique (APT)" in Solar Energy Materials and Solar Cells, Vol. 81, pp. 101.

[22] Patil R.S., Uplane M.D. and Patil P.S. (2006) "Structural and Optical Properties of Electrodeposited Molybdenum Oxide Thin films" in Applied Surface Science, Vol. 252, pp. 8050.

[23] Ilican, S., Caglar, Y. and Caglar, M., (2008) "Preparation and Characterization of $\mathrm{ZnO}$ Thin Films Deposited by Sol-gel Spin Coating Method" in Journal of Optoelectronics and Advanced Materials, Vol. 10, No. 10, pp.2578-2583.

[24] Hankare, P.P., Jadhav, B.V., Garadkar, K.M., Chate, P.A., Mulla, I.S. and Delekar, S.D. (2010) "Synthesis and Characterization of Nickel Selenide Thin Films Deposited by Chemical Method" in Journal of Alloys and Compounds, Vol. 490, pp.228-231. 